\title{
HÁLÓZATOK A NYELVBEN
}

A kötet kolofonjának tájékoztatása szerint az ELTE Bölcsészettudományi Kar Mai Magyar Nyelvi Tanszékének Új nézőpontok a magyar nyelv leírásában 7. A nyelv hálózatos leírása címmel 2018. november 22-23-án tartott konferenciájának válogatott, tanulmánnyá bővített lektorált elöadásait tartalmazza. A több mint harminc szerző hazai és külhoni akadémiai, felsőoktatási intézménybeli és más kutatóhelyek munkatársa vagy éppen doktorandusza (lásd a perszonáliákat a könyv végén). A tanulmányok nem tematikus csoportokban, hanem íróik neve szerinti ábécében találhatóak, ezért bizonyos témakörönként kísérlem meg bemutatni a könyvet.

A hálózatelmélet jelentősége, mibenléte és újabban való elterjedése Csermely Péter bemutatásában olvasható, aki szerint ,az ember hálózatképző állat”. A tudományosságban ez azt jelenti, hogy manapság ezer és ezer okot vagyunk képesek föltárni, ezek megértésének egyik technikai eljárása a hálózatkutatás, amely csupán akkor hasznos eljárás, ha nagyon sok háttér-információ van a vizsgálandó területről, különben - írja a jeles kutató - „a hálózatkutatás semmire nem jó az égadta egy világon". A jelenségek vizsgálatához megfelelő identitású nódusokat (azaz elemeket, pontokat, részeket) kell definiálni a hálózatban. A határozottan eltéró jelenségeket, dolgokat valamiképpen - akár véletlenszerüen - kombinálni kezdi a kutatás, ekként tárulnak vagy tárulhatnak föl összefüggések, mint a vizsgálat eredményei. A szokványos és az új helyzetekre adott válaszokhoz való hálózatos alkalmazkodás kétfajta hálózatos szerkezetet alakít ki - írja Csermely Péter. Az egyik egy plasztikus rendszer, amelyik tanulóképes, a másik a merev rendszer, amelyik viszont nem tanulóképes, viszont nem felejt.

A nyelv rendszerként mindkét Csermely által említett tulajdonság birtokosa, ezért is, továbbá a nagy mennyiségü információtartalma miatt ugyancsak alkalmas a hálózatkutatás szerinti vizsgálatra. Ez a nyelvészet különbözö részterületeire vonatkoztatható. A tanulmánykötetben az élő (hangzó) beszéd, az alaktan, a szótan, a mondattan, a jelentéstan, a szövegtan, valamint a stilisztika köréből olvashatók tanulmányok.

Keszler Borbála és Bóna Judit dolgozata - a beszédszünetek és a beszédtempó változása évtizedek távlatában - azon alapul, hogy a beszéd beszédszakaszok és szünetek váltakozásából álló hálózat, amelyben a temporális jellemzők egyrészt függnek a beszédszervek biológiai állapotától. A különféle korosztályok beszédének adatolása bizonyítja, hogy az életkor nem (egyformán) befolyásolja a beszédtempót és az artikulációs tempót minden beszélőnél.

Morfológiai tárgyú Palágyi Lászlónak az -Ó és-Ás képzős alakok és alapigéik hálózati megközelitése címú írása. Palágyi szerint ,,a nyelvi hálózat legfőbb jel- 
lemzői pedig a szimbolikusság, a példányalapúság, a hierarchikusság és a produktivitás. Az e jellemzők kapcsán magyarázóerővel bíró általános kognitív folyamatok a modalitásközi asszociáció, a memória, a tömbösítés és az analógia". Elemzése ennek megfelelve tekinti át a futó - futás típusú alakulatok összefüggésrendjét. A vizsgálatba vont alaktani konstrukciók morfoszemantikai, morfoszintaktikai és morfofonológiai viszonyai közötti erősebb és lazább összefüggésekben lát a szerző hálózatot.

A szótan egy részterületének kutatása Lugosi Teleki Enikő munkája: Onomatopoetikus sémák, csoportosulások rokon értelmü mozgásigék szemléltetésével. A tanulmányíró a hangutánzó (hanggal festő) szavak fölépítésének különféle jegyeit (igető, képzők, szótagszám stb.) tekinti át „,funkcionális nyelvelméleti megközelítésben”, majd arra az eredményre jut, hogy „,[s]okszoros fonetikai, morfológiai, szemantikai együtthatás, hálózat jelentkezik a rokon értelmủ szavak mentén", ezért szerinte a rokon értelmủ szavak mintázatok alapján csomópontokba, hálózatokba rendeződnek. A Csermely Péter által említett nóduskijelölésre gondolva mindez - mondhatni - bármely nyelvi elemhalmazra érvényes. - Ugyancsak az ún. funkcionális kognitív alapállás szerinti dolgozat Mayer Péteré (Hálózat a hálózatban. Mozgásigék és határozóragos vonzataik vizsgálata a konkrét-absztrakt jelentéskiterjesztés szempontjából), aki az állandó határozókat (például szembefut vki vkivel vmivel) törekedik az említett funkcionális kognitív szempontból leírni. Vizsgálatai „az állandósulás pontatlan fogalma helyett új módon kínálják fel a szerkezeti stabilizálódás leírását", ez a hálózatba tett (és főként szemléltetésként rajzolt) vonzatokról végül is az állandósulás egyik elemét tartja fontosnak.

Pomázi Bence szintén olyan vonzatokról értekezik (Igei és melléknévi alaptagú, verbális és deverbális vonzatszerkezetek), amelyeknek például a fél igei és a lusta melléknévi alaptagjaik vannak, például „fél a sötétben vezetni”, „lusta idejében felkelni”. A szerző szerint tanulmánya kiindulópontjának tartja, hogy a vonzatstruktúrák eltérő konstruálási módjai egy asszociatív hálózat tagjaiként foghatók föl. Voltaképpen az állítmány kötelező bővítményeinek viszonyhálózatba helyezése alapján kíséreli meg a nyelvi leírást-magyarázatot.

Imrényi András dolgozata a „milyen hálózat a magyar mondat” kérdéssel foglalkozik. Ez a kérdés, illetve a hálózat terminus mondattani alkalmazása már Brassai Sámuel 19. század közepi és Elekfi László 20. század közepi munkáiban megjelent a hazai nyelvleírásban. Mivel ,a mondat jelentésével kapcsolatban többféle kérdést is fel lehet tenni, amelyek egymást kiegészítő szempontokat adnak a mondat jelentésszerkezetének elemzéséhez", több dimenziót alkalmaz a szerző: a mondat ábrázoló szerepét, közlési funkcióját és kontextusbeli elhelyezését. Ennek alapján így zárja a dolgozatot, némileg cáfolva a tanulmány címét: „A jövőben az elméleti javaslat további kidolgozása mellett fontos feladat lesz a korpusznyelvészethez, illetve a hálózatkutatáshoz való kapcsolódás." 
Szövegnyelvészeti tárgyú a Domonkosi Ágnes, Kuna Ágnes és Ladányi Zsófia által jegyzett, Az irásbeli üzenetváltás szövegtípusainak hálózati jellege címü tanulmány. H. Tomesz Tímea elemzése a Sportesemények a médiaszövegek hálózatában ugyancsak e tárgycsoporthoz tartozik, az ún. „újmédia” eljárásait tekinti át, amelyek a szöveg befogadója érdekeit szolgálják a kapcsolódások révén.

A stílusvizsgálat ugyancsak kínálja a hálózatelméleti módok alkalmazását. Simon Gábor a megszemélyesítés nyelvi szerkezetei hálózatokként való modellálhatóságát kívánja megoldani (Hálózatos megszemélyesítések - megelevenítő hálózatok) József Attila megszemélyesítéseit gráfrendszerbe téve törekedik erre. Végül megállapítja, hogy „sem a megszemélyesítésnek, sem a megelevenítésnek nincsenek tipikus, jellemző hálózati szerveződési módjai”. Füst Milán-i jegyek egy korai Illyés-versben címmel a szóelőfordulások azonosságának egybevetésével törekedik föltárni a fiatal Illyés Gyulára tett (stílus)hatást - jelen ismertetés szerzőjének - írása.

Az olvasó a fenti főbb csoportok mellett még más nyelvészeti terület müvelöitől is találhat munkákat, így például a névtan körébe sorolható a testrészek konceptualizációjának (Baranyiné Kóczy Judit), a ragadványnevek szociometriai hálózatának (Blankó Miklós), valamint Sepsikőröspatak és Kálnok helyneveinek (Már Orsolya) tárgyalása.

Balázs Géza tanulmánya (Szimmetria a müvészetben és a nyelvben) címében is mutatja, hogy nem csupán a nyelv vizsgálható valamely szempontból hálózatrend szerint, minthogy ,[a] szimmetriák komplex képi és nyelvi hálózatokat alkotnak, hálózattudományi szempontból az egymásba ágyazottság a fó jellemzőjük". A szerző számos példával mutatja be és igazolja a szimmetria meglétét a címben megjelölt területek, illetve a természeti jelenségek körében.

A kötet összes és a föntiekben említett tanulmányait a nyelvészek és a hálózatkutatók egyaránt haszonnal olvashatják. Előbbiek viszonylag új vizsgálati módokat és az esetleges eredményeket vethetik össze a korábbi tudományosságéval, utóbbiak meggyőződhetnek arról, hogy a hálózatfelfogás mibenléte átitatta-e ezeket a nyelvészeti vizsgálatokat, vagy csupán annak igyekezete mutatkozik meg.

(Balázs Géza - Imrényi András - Simon Géza szerkesztők: Hálózatkutatás - Hálózatok a nyelvben. Budapest: Magyar Szemiotikai Társaság, 2020, 370 o.)

Büky László nyelvész 